\title{
Corrosion Mechanism in the Obsidian and its Comparison with the Nuclear Waste Glass for Long-Term Performance Assessment in the Geological Repository
}

\author{
Nishi Rani ${ }^{1}$, J. P. Shrivastava ${ }^{*}, 1$ and R. K. Bajpai ${ }^{2}$ \\ ${ }^{1}$ Department of Geology, University of Delhi, Delhi - 110007, India \\ ${ }^{2}$ BETDD, Nuclear Recycle Group, BARC, Mumbai - 400008, India
}

\begin{abstract}
Present paper discusses experimental work on obsidian glass to understand corrosion mechanism at variable pressure temperature conditions. For comparison, Advanced Vitrification System, a nuclear waste glass was studied simultaneously under similar conditions. Owing to massive weight loss the glass samples were unable to sustain beyond 4 hour during the experiments. Corrosion experiments on both these glasses were performed under hydrothermal like conditions and observed that the changes in the experimental conditions have major control over the release of sodium and other ions from obsidian and nuclear waste glass, hence effecting corrosion mechanism. X-ray diffraction patterns of the residue obtained after the experiments on obsidian glass revealed appearance of neo-formed minerals, such as quartz, celadonite, halloysite, sodalite, heulandites and wairakite. High degree of corrosion and formation of amorphous residue observed in case of the experiments performed at $300^{\circ} \mathrm{C}$ over the granules of the nuclear waste glass. The back scattered electron images of the scanning electron microscope indicate distinctive microstructures, associated with the neo-formed minerals, and their formation is linked with the release of sodium, potassium and other ions, causing changes in the $\mathrm{pH}$ and conductivity of the leachate. In case of nuclear waste glass back scattered images of the scanning electron microscope indicates formation of multiple alteration layers and secondary alteration products. The surface of the pellet after the experiment shows phyllosilicate with numerous tiny spherules embedded within the structure. These experimental results when extrapolated suggest formation of amorphous silica, quartz and chalcedony as end members in case of obsidian glass whereas, formation of iron rich fayalite and greenalite can be observed in case of nuclear waste glass. The mechanism, conditions of formation of neo-formed minerals and their stability have been discussed in the paper.
\end{abstract}

Keywords: Corrosion, obsidian, advanced vitrification system glass, hydrothermal conditions, microstructures, modeling and simulation.

\section{INTRODUCTION}

Glass is considered as a suitable matrix for immobilization of high-level nuclear waste [1-4]. The process of vitrification to borosilicate glass is advanced, involving assimilation of nuclear waste into high-silica glass, and to develop corrosion resistant and highly durable waste matrix. Borosilicate glass is chemically durable and well suited for achieving high loading of nuclear waste [5]. For vitrification of High Level Waste (HLW), borosilicate matrix is widely used in India [6]. Vitrification results in the transformation of highly corrosive liquid wastes into a more compact and manageable solid. In case of silicate glasses, the dissolution rate is highly dependent on factors such as, temperature, $\mathrm{pH}$ and solution composition, particularly the activity of silicic acid [7]. Predictions of rate of glass dissolution on long-term basis and release of radionuclide in geological repository require an understanding of glass and environmental reactions [8]. However, structure of complex glasses has not been very well understood [9].

*Address correspondence to this author at the Department of Geology, University of Delhi, Delhi - 110007, India; Tel: +91-11-27667073; Fax: +91-11-27666295; E-mail: jpshrivastava.du@gmail.com
Behaviour of water-rock system primarily depends upon the reaction rates of rock-forming minerals or glasses on a geological time-scale. The affected rocks often alter at conditions at or near chemical equilibrium in the natural hydrothermal system. Experimental studies carried out on silicate minerals and glasses, provided kinetic data concerning the initial stages of dissolution at conditions of high saturation of the fluid with respect to the dissolving material. It has been found that the dissolution rate is controlled by the chemical reactions which occur at the solid-solution interface [10]. The identification of the main elementary steps of the dissolution reactions [11-16] have concluded that the leading role is played by chemical species at the solid surface.

Basaltic glasses of volcanic origin are considered as natural analogue for nuclear waste glasses, used to contain fission product solutions and provide data on the alteration behaviour of vitreous materials over geological time scale. The analogy between basaltic and nuclear glasses has been extensively documented with respect to their secondary products formed during alteration of these materials [17-21]. The aluminosilicate nepheline syenite glass shows low order of leach rates as compared to borosilicate glass [22, 23]. The rhyolite glass survives in the natural environment for several 
million years therefore, considered as a natural analogue for nuclear waste glass $[24,25]$. Previous studies on dissolution behaviour of acid volcanic glass were mainly aimed at their potential utility as nuclear waste hosts whereas, hydrothermal leach tests on rhyolite glass were performed $[26,27]$ for a limited period and recognized only one notable exception of aluminosilicate nepheline syenite glass (used in the pioneering Canadian study), which represents lower leach rates than that of the borosilicate glass. Experimentally determined leach rates for rhyolite glass is much lower than that of the synthetic nuclear waste glass $[19,27]$. The extrapolation results for long-term performances of these glasses are indistinct. Based on these results, basalt glass was considered as a natural analogue for radioactive waste containment [28-34].

In contrast to several studies $[19,26,27]$ focused on the dissolution rates of basaltic and borosilicate glasses, the corresponding studies on acid volcanic glasses are rare thus, present study is necessary to predict and to extrapolate corrosion mechanism in these glasses. Attempt has been made to find out its analogy with that of the nuclear waste glass. For this purpose, experiments were performed with the obsidian under near hydrothermal conditions in a laboratory time framework to understand corrosion mechanism in the obsidian glass. With a focus on the long-term behaviour of nuclear waste stored in a geological repository, these results were compared with the data obtained under similar alteration conditions for AVS. The specific effect of dissolved silica on the dissolution kinetics was assessed by means of alteration experiments. The glass behaviour is modeled using EQ3/6 and GWB geochemical codes [35, 36] taking into account the equilibrium distribution of aqueous species in a fluid, the fluids saturation state with respect to minerals and the sorption of aqueous species onto surfaces.

\section{EXPERIMENTAL PROTOCOL}

\subsection{Obsidian Glass}

Fresh unaltered obsidian was chipped out from a working quarry. Samples are optically translucent, pitch black to dark brown in colour, shows vitreous lustre. It is often banded having conchoidal fractures. Major oxide composition was determined by XRF technique (Table 1) and compared with the published data of $[37,38]$, indicating a tight chemical closeness. When plotted over Total Alkali-Silica diagram. These data plots lie close to each other and confine to a rhyolite field.

To achieve optimum S/V (surface area/volume) ratio for the test glass, obsidian chips were pulverized and sieved to obtain particle size of 100-120 $\mu \mathrm{m}$. Glass specimens were prepared after the glass powder was ultrasonically cleaned in deionized water and allowed to dry at $90^{\circ} \mathrm{C}$ for 24 hours. The specific area and density of each specimen was determined by BET (Krypton) measurements [39]. These values are of obtained are in the order of $663 \mathrm{~cm}^{2} / \mathrm{g}$ and $2.405 \mathrm{~g} / \mathrm{cm}^{3}$, respectively.

\subsection{Waste Glass}

Simulated waste used in this investigation, represents its composition close to the HLW to be processed. The $\mathrm{Na}_{2} \mathrm{O}-$ $\mathrm{B}_{2} \mathrm{O}_{3}-\mathrm{SiO}_{2}$ ternary was used as a basic system for the matrix composition selection. Glass made up from this system is referred to base glass. Before selecting the base glass compositions, relevant $\left(\mathrm{BaO}-\mathrm{B}_{2} \mathrm{O}_{3}-\mathrm{SiO}_{2}, \mathrm{Na}_{2} \mathrm{O}-\mathrm{B}_{2} \mathrm{O}_{3}-\right.$ $\mathrm{SiO}_{2}, \mathrm{BaO}-\mathrm{Na}_{2} \mathrm{O}-\mathrm{SiO}_{2}$ ) ternary diagrams have been studied by [40-42] were considered. Major elemental compositions of AVS glass specimen was determined using XRF technique (Table 1). Glass specimens of $100-120 \mu \mathrm{m}$ size granule was prepared and ultrasonically cleaned in deionized water and allowed to dry at $90^{\circ} \mathrm{C}$ for 24 hours. The specific area and density of specimen was determined by BET (Krypton) measurements [39].

Table 1. Major Elemental Composition of Waste Loaded AVS Glass (wt \%)

\begin{tabular}{|c|c|c|c|}
\hline Oxides (Wt \%) & AVS & Oxides (Wt \%) & Obsidian \\
\hline \hline $\mathrm{SiO}_{2}$ & 40.602 & $\mathrm{SiO}_{2}$ & 71.18 \\
\hline $\mathrm{B}_{2} \mathrm{O}_{3}$ & 22.094 & $\mathrm{TiO}_{2}$ & 00.36 \\
\hline $\mathrm{TiO}_{2}$ & 08.036 & $\mathrm{Al}_{2} \mathrm{O}_{3}$ & 09.71 \\
\hline $\mathrm{Na}_{2} \mathrm{O}$ & 20.832 & $\mathrm{Fe}_{2} \mathrm{O}_{3}{ }^{\mathrm{T}}$ & 05.26 \\
\hline $\mathrm{Fe}_{2} \mathrm{O}_{3}{ }^{\mathrm{T}}$ & 05.536 & $\mathrm{MnO}$ & 00.11 \\
\hline $\mathrm{K}_{2} \mathrm{O}$ & 00.227 & $\mathrm{MgO}$ & 00.11 \\
\hline $\mathrm{CeO}_{2}$ & 01.286 & $\mathrm{CaO}$ & 01.96 \\
\hline $\mathrm{MnO}$ & 0.462 & $\mathrm{Na}_{2} \mathrm{O}$ & 05.51 \\
\hline $\mathrm{Cr}_{2} \mathrm{O}_{3}$ & 0.193 & $\mathrm{~K}_{2} \mathrm{O}$ & 00.03 \\
\hline $\mathrm{Cs}_{2} \mathrm{O}$ & 0.178 & $\mathrm{P}_{2} \mathrm{O}_{5}$ & 05.76 \\
\hline $\mathrm{MoO}$ & - & - \\
\hline $\mathrm{BaO}$ & 0.173 & - & - \\
\hline $\mathrm{SrO}$ & 0.206 & - & - \\
\hline $\mathrm{Total}$ & 100 & $\mathrm{Total}$ & 100 \\
\hline
\end{tabular}

\section{CORROSION PROCEDURES FOR OBSIDIAN GLASS}

For obsidian glass twenty-one set of alteration experiments were performed separately in the corrosion resistant, high pressure - temperature Parr Reactor (Model: 4568). In this reactor, each $1.0 \mathrm{gm}$ of glass specimen was treated with $80 \mathrm{ml}$ of deionized water at 100,200 and $300^{\circ} \mathrm{C}$ and 50, 250 and 1260 psi, respectively for $1,2,4,8,16,32$ and 64 hours (Table 2). After experiments, residue of neoformed minerals and the leachates were obtained. The neoformed altered crystalline mineral phases formed in case of obsidian glass were studied using X-ray diffraction and SEM techniques.

For the AVS, alteration experiments under similar set up were carried out but, for a limited period of 30,60,120 and 300 minutes The optically polished glass pellets $(3 \mathrm{~mm}$ thickness and $2.5 \mathrm{~cm}$ dia.) of Vitrified Waste Product (VWP) were selected for PHWR (Pressurized Heavy Water Reactor) high level waste immobilization, subjected to induced hydrothermal conditions at 100,200 and $300^{\circ} \mathrm{C}$ in the Parr Reactor with deionized water. The surface area to volume of leachant $(\mathrm{S} / \mathrm{V})$ ratio is maintained to the order of $0.15 \mathrm{~cm}^{-1}$ which favours rapid attainment of steady state corrosion through the rapid release of silica and other constituents to saturated conditions. After experiments the residue (of neo- 
formed minerals) and the leachates were studied. Electrical conductivity and $\mathrm{pH}$ measurements were made for the leachates. Surface morphology of the neo-formed crystalline mineral phases in the glass was studied using SEM - EDS and high flux XRD techniques, respectively.

Table 2. Summary of the Alteration Experiments Under Accelerated Pressure Temperature Conditions

\begin{tabular}{|c|c|c|}
\hline Test Type & Static & Static \\
\hline Glass & Obsidian & AVS \\
\hline Grain size & $100-120 \mu \mathrm{m}$ & $100-120 \mu \mathrm{m}$ \\
\hline Weight & $1 \mathrm{gm}$ & $1 \mathrm{gm}$ \\
\hline Leachant & Deionized water & Deionized water \\
\hline Volume & $80 \mathrm{ml}$ & $80 \mathrm{ml}$ \\
\hline Temperature & 100,200 and $300^{\circ} \mathrm{C}$ & 100,200 and $300^{\circ} \mathrm{C}$ \\
\hline $\mathrm{S} / \mathrm{V}$ ratio & $80 \mathrm{~cm}^{-1}$ & $80 \mathrm{~cm}^{-1}$ \\
\hline Duration & 1 to 64 hours & 15 mins to 5 hours \\
\hline
\end{tabular}

\section{RESULT AND DISCUSSION}

\subsection{Calculation of Alteration Rate}

Generally, boron is considered as a reaction tracer for the evaluation of glass alteration mechanism but, it is very low in concentration in obsidian hence, its aqueous dissolution has not been taken into account. Sheng et al. [43] have discussed that $\mathrm{Na}$ participates easily in the ion exchange reaction with water, therefore $\mathrm{Na}$ concentration along with $\mathrm{K}$ and $\mathrm{Fe}$ (in AVS glass) as an additional check has been taken into account for the present calculations. Mass loss and release rates for $\mathrm{Na}, \mathrm{K}$ and $\mathrm{Fe}$ (in AVS glass) have also been calculated to evaluate glass alteration mechanism. To quantify mass loss, mass of each glass specimen was measured before and after the experiments by following procedure of [43].

Total mass loss $M L=\left(m_{o}-m_{1}\right) /(S A)$

where,

$M L=$ total mass loss $\left(\mathrm{g} / \mathrm{m}^{2}\right)$

$m_{o}=$ total unaltered glass specimen in $\mathrm{gm}$

$m_{1}=$ total altered glass specimen in $\mathrm{gm}$

$S A=$ the sample surface area

Kaushik et al. [44] have discussed that the normalized mass loss is linked with the rate of release of sodium concentration in solution. It corresponds to the mass of the glass altered in the unit surface area $\left(N L_{i}\right)$, using following equation. Normalized mass loss for each glass specimen is calculated after the experiment.

[(Na leached / Na present in the sample) $x$ wt. of sample] / surface area $\left(\mathrm{cm}^{2}\right)$ x time (days)

(Eq. 2)

\subsection{Evolution of the $\mathrm{Na}$ and $\mathrm{K}$ ions in the Leachate}

Previous studies concluded that the glass water interaction comprises chemical reactions and mass transport processes. It has been established that the ion-exchange, network hydrolysis and precipitation are important mechanisms of glass leaching [45-47]. Precipitation reactions usually play important role under saturated conditions (for long-term performance) whereas, ion exchange and network hydrolysis are the dominant processes (under short term or weak alteration conditions). To understand relationship between elemental release and rate of alteration with respect to time, weight loss and leachrate $\left(\mathrm{gm} / \mathrm{cm} / \mathrm{min}^{2}\right)$ of glass has been measured (Figs. 1, 2). For this, data plots between the time (in hours) of alteration of glass vs. $\mathrm{Na}, \mathrm{K}$ and $\mathrm{Fe}$ release (in $\mathrm{mmol} / \mathrm{l}$ ) were plotted (Figs. 3-5).

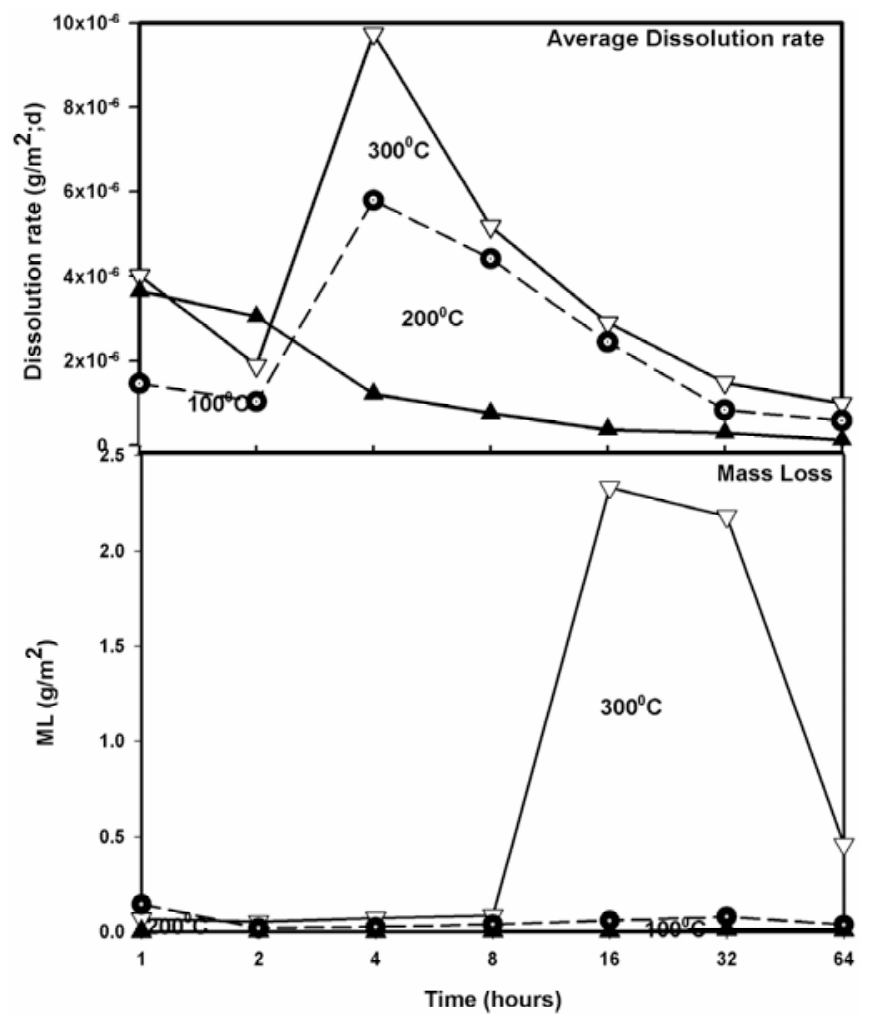

Fig. (1). Average dissolution of obsidian glass.

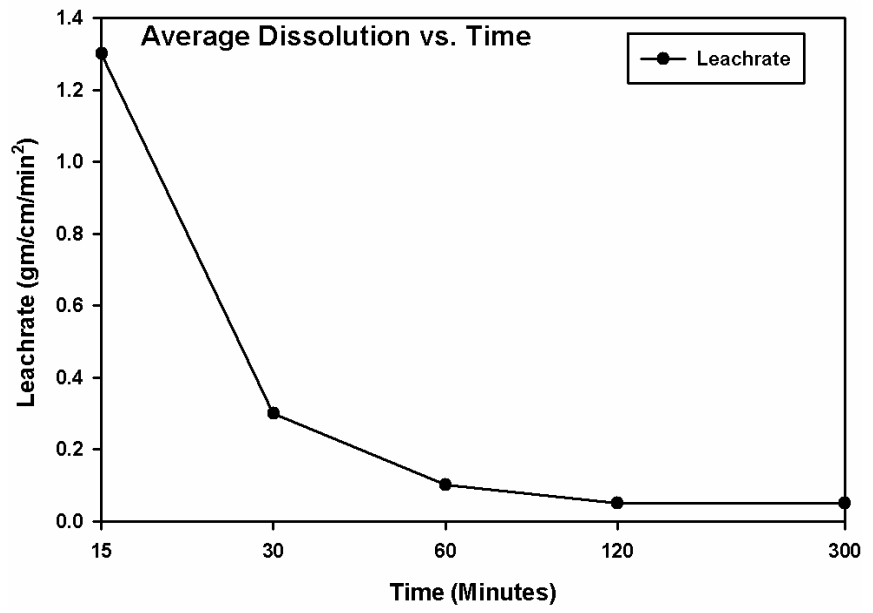

Fig. (2). Average dissolution of AVS glass.

To understand these mechanisms in case of obsidian glass, $\mathrm{Na}, \mathrm{K}$ and $\mathrm{Fe}$ ions present in the leachates were determined by Flame photometer and Atomic Absorption 


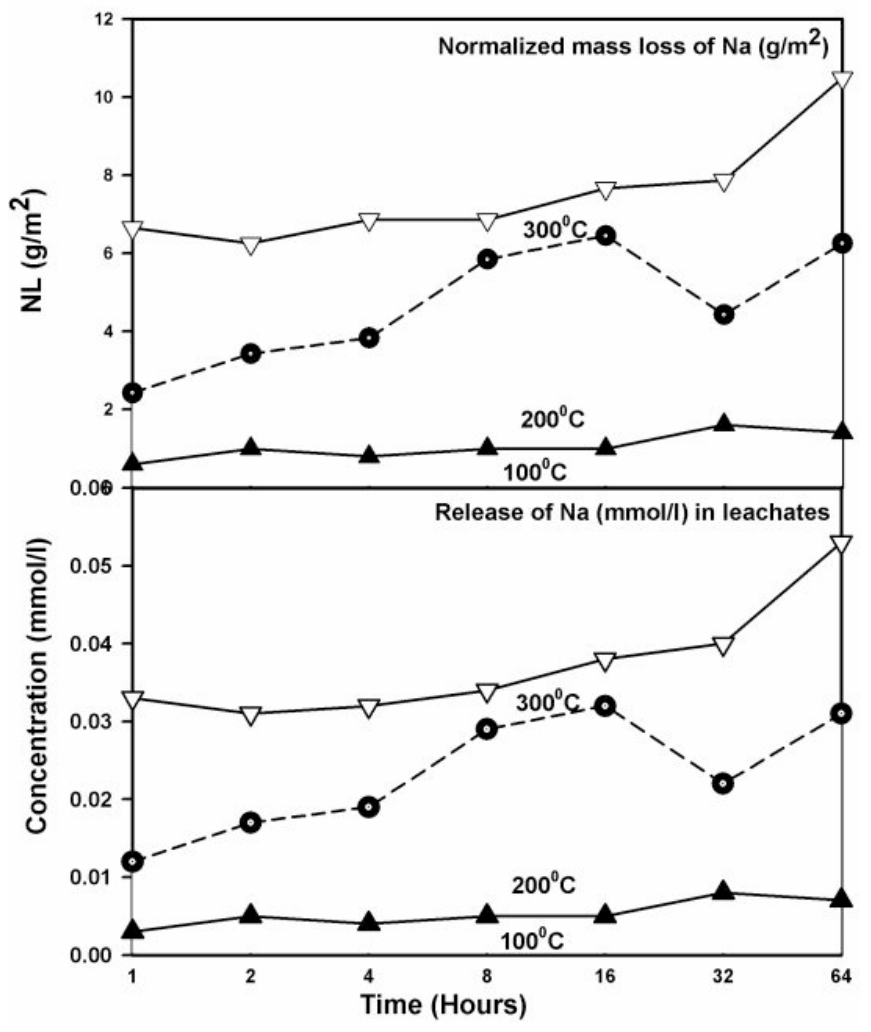

Fig. (3). Trend of Sodium release in obsidian glass.

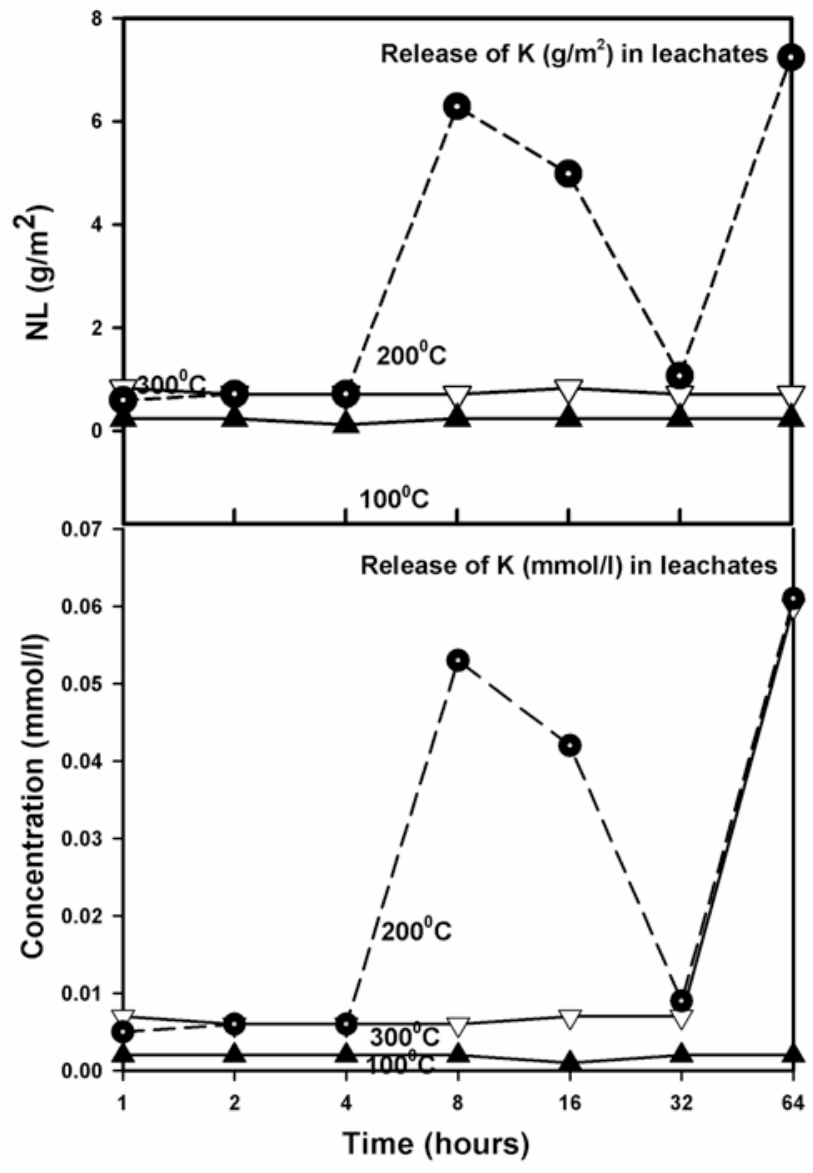

Fig. (4). Trend of potassium release in obsidian glass.

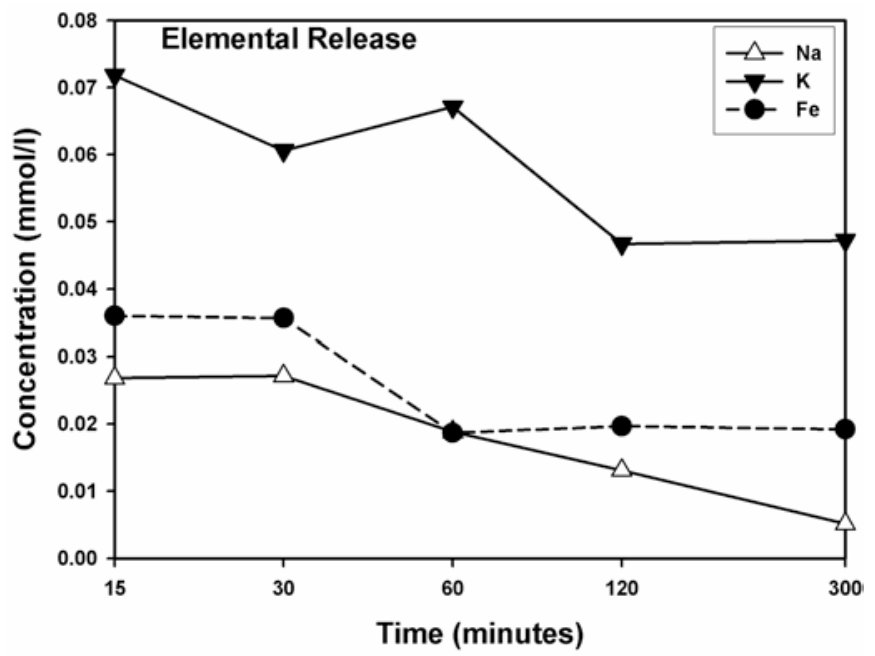

Fig. (5). Trend of elemental release in AVS glass.

Spectroscopy. When time vs. $\mathrm{pH}$ (as a function of temperature) data plots, indicated that the $\mathrm{pH}$ value rises with the increase in the time and temperature both. The maximum $\mathrm{pH}$ (8.03) recorded in the leachate is obtained after treatment of the specimen for 64 hours in the reactor. These glasses contain 5.51 and $15.05 \% \quad \mathrm{Na}$ content respectively, participating in the ion exchange reactions with water. The high release of $\mathrm{Na}$ ions in water led to form a weaker network structure than that of the high level waste (HLW) glass, and subsequently it is more readily attacked by the water. The elevated participation of ion exchange process, particularly when high $\mathrm{S} / \mathrm{V}$ ratio of the test sample is available, causes overall release of elements which is perhaps responsible for the increase in the $\mathrm{pH}$ values of leachates [43]. It indicates appearance of buffering effect on ion-exchange process during the entire range of alteration test. The initial reaction causing alkali release resulted from water diffusion into the glass network. As the release rate decreases with the increasing depth of the alkali depletion zone in the outer glass surface, matrix dissolution becomes the dominant process.

The data plots (Fig. 5) between time and release of $\mathrm{Na}, \mathrm{K}$ and $\mathrm{Fe}$ ions indicate that the sodium ion concentration increases commonly in the AVS glass, however in case of obsidian, preferential release of potassium ions is observed (Fig. 4), indicative of large scale breaking of the glass network, hence more glass dissolution is taking place. It has been found that the release of potassium ions was less than that of the sodium ions. These glasses contain preferential $\mathrm{Na}$ content (5.51 and $15.05 \%$ respectively), participating in the ion exchange reactions with water. The high release of $\mathrm{Na}$ ions in water led to form a weaker network structure than that of the high level waste (HLW) glass, and subsequently it is more readily attacked by the water. The release of $\mathrm{Na}$ ions in water led to form a weaker network structure than that of the high level waste (HLW) glass, and subsequently it is more readily attacked by the water.

To describe leaching behaviour, the ratio of concentration of other elements to the amount of silica in the leaching solution is calculated and compared this ratio with that of the unaltered glass matrix. These results indicate that $\mathrm{pH}$ of the leachate plays a dominant role in the leaching of simulated waste glasses [43]. Dissolution rates of silicate 
minerals and glasses, measured in the laboratory indicate that weathering is mainly controlled by the $\mathrm{pH}$-dependent detachment of framework elements from the solid surfaces suggested by [15, 48-50].

The ion-exchange reactions dominated the HLW glass corrosion process when the $\mathrm{pH}$ of the leachate is more than 9 , whereas hydrolysis reactions dominate glass dissolution at a $\mathrm{pH}$ less than 9 [51]. A high leach rate is attributed to the effects of the solution composition effects, because as elemental concentration increases in the leachate, elemental release rate generally decreases [52]. In case of granules, weight loss is considerably high and the equilibrium leach rate condition is achieved in a short duration.

\subsection{XRD Patterns and Surface Characterization Of Residue}

For X-ray diffraction analyses, the oriented mounts were prepared and scanned using Philips (Model: X'pert, PW 1830) diffractometer with $\mathrm{Cu}-\mathrm{K} \alpha$ radiations at an adopted scanning speed of $1^{\circ} / \min$ for 5 to $40^{\circ}$. However, beyond $40^{\circ}$ diffraction patterns do not show significant bands. These diffraction patterns indicate that untreated obsidian glass is gradually changing into a crystalline phase. At $300^{\circ} \mathrm{C}$ for 1 hour treatment of the sample (Sample No.3A), the release rate of sodium ions increases slightly while, in this case release of potassium ions is on the lower side and these ions contributing to the formation of heulandite. There is a considerable variation in the $\mathrm{Si} / \mathrm{Al}$ ratio with concomitant variation in the proportion of $\mathrm{Ca}$ and $\mathrm{Na}$. Since the structure of heulandite consists of a very open Si-Al-O framework in which two- third of the ( $\mathrm{Si}, \mathrm{Al}) \mathrm{O}_{4}$ tetrahedra are linked to form network of six-membered rings, parallel to $\{010\}$ [53]. Only small substitution of potassium for sodium leads to the formation of sodalite [53]. Presence of wairakite is inferred in the residue which is calcium analogue of analcite. It forms by partial replacement of sodium by potassium and the substitution of aluminium for silica. Such mechanism is also possible for the formation of wairakite in these specimens (Specimen No. 3G). The treatment of glass samples (Specimen No. 3G) at $300^{\circ} \mathrm{C}$ for 64 hours causing an elevated release of sodium, indicative of high cation exchange capacity which is perhaps responsible for the formation of halloysite [54]. The lattice parameters in respect of altered glass samples (Specimen No 3A, 3B and 3G) after the experiments were calculated in Table 3, using Bragg's equation for the cubic, hexagonal and monoclinic systems. X-ray diffraction patterns and cell dimensions in Table 3 of the treated samples at $300^{\circ} \mathrm{C}(\mathrm{pH}=8.03)$ when compared with the published [54] values revealed appearance of heulandite $(\mathrm{a}=17.18, \mathrm{~b}=17.89$ and $\mathrm{c}=7.428 \AA)$, saponite $(\mathrm{a}=5.3, \mathrm{~b}=9.16$ and $\mathrm{c}=12.4 \AA)$, quartz $(\mathrm{a}=4.9133$ and $\mathrm{c}=5.4053 \AA)$, halloysite $(\mathrm{a}=5.14, \mathrm{~b}=8.9$ and $\mathrm{c}=14.9 \AA)$, sodalite $(\mathrm{a}=8.85 \AA)$, wairakite $(\mathrm{a}=13.692, \mathrm{~b}=13.643$ and $\mathrm{c}=13.56 \AA)$ and celadonite $(\mathrm{a}=5.233, \mathrm{~b}=9.047$ and $\mathrm{c}=10.197$ $\AA$ ). For nuclear waste glass (AVS), same procedure was followed for XRD studies however, the diffractograms of the treated granules revealed that residue is amorphous but, for a sample treated at $300^{\circ} \mathrm{C}$, single anomalous quartz peak was observed. The high flux XRD study was also carried out on pellets, which indicates that the crystalline phase is formed. The XRD study on the pellet surface of the pellet indicates formation of secondary crystalline quartz in addition to mineral phases of phyllosilicate and sodium titanium silicate. These samples were air dried and subjected to surface morphological characterization with SEM - EDS. The visual assessment of swollen pellet indicates formation of clay minerals with the globules on the periphery (Fig. 6). The elemental distribution profile from surface to bulk was carried out by analyzing the cross section of an altered pellet. Dissolution of vitreous material involves preferential dissolution of network modifiers $(\mathrm{Na})$ and network formers (B) with the formation of residual $\mathrm{Si}$ rich hydrated layer which accommodate precipitated crystalline as well as amorphous phases. Further increase in $\mathrm{pH}$ increases, favours matrix dissolution with the formation of altered layers. The scanning electron microscopic study over the surface indicates formation of multiple alteration layers as well secondary products. EDS analysis of outermost leached layer indicates that it is rich in $\mathrm{Ti}, \mathrm{Mn}$, and $\mathrm{Fe}$ and largely depleted in Na. The cross section of the pellet indicates surface layers and highly porous inner altered glass region (Fig. 7). Optical microscopy of the cross section of pellet (allowed to corrode for 24 and 48 hours) indicates surface alteration with dense glassy phase in the centre, while for the pellet leached for 72 hours indicate complete transformation into uniformly porous altered glass matrix (Fig. 7). Optical microscopy and SEM-EDS analysis of the surface of the samples indicate formation of leached layer and deposition of secondary crystalline materials (Fig. 7). The surface of the pellet shows presence of phyllosilicate with numerous tiny spherules embedded within the structure (Fig. (8a). The surface of the rim appears like a foliated clay mineral (Fig. 8b), but the whole rim is more bulky (Fig. 8c). It consists of equidimensional glass grains with shard morphology hence particles similar to smectite in morphology (Fig. 8d) are observed. Untreated sample of obsidian glass is also considered for scanning electron microscope (Fig. 9a). Glass particles are differentiated into two types by morphology. The other particles show appearance of altered surfaces clustered to form massive aggregates (Fig. 9b) and platy flakes similar to smectite (Fig. 9c). Complete transformation of glass into neoformed mineral can be observed (Fig. 9d). The more abundant population is comprised of particles with clean surfaces (Fig. 9e, f). Owing to low crystallinity these particles do not show electron diffraction patterns. Untreated sample is also considered for scanning electron microscope (Fig. 10a). The surface of the rim appears foliated like a clay mineral (Fig. 10b), but the whole rim is more bulky (Fig. 10c). It consists of equidimensional glass grains with shard morphology hence particles similar to smectite in morphology (Fig. 10d) are observed. Glass particles are differentiated into two types by morphology. The more abundant population is comprised of particles with clean surfaces (Fig. 10e, f). The other particles show appearance of altered surfaces clustered to form massive aggregates (Fig. $\mathbf{1 0 g}$ ) and platy flakes similar to smectite (Fig. 10h). Owing to low crystallinity these particles do not show electron diffraction patterns.

\section{MODELING AND SIMULATION}

In kinetic reaction paths, the rates at which minerals dissolve into or precipitate from the equilibrium are set by 
Table 3. Lattice Parameters of Minerals Identified in XRD

\begin{tabular}{|c|c|c|c|c|c|c|c|}
\hline \multirow{2}{*}{ Time (hrs) } & \multirow{2}{*}{ pH } & \multirow{2}{*}{ Neoformed Minerals } & \multicolumn{3}{|c|}{ Cell Dimensions } & \multirow{2}{*}{ Lattice Type } & \multirow{2}{*}{ Crystal System } \\
\hline & & & $\mathbf{a}$ & b & c & & \\
\hline \multicolumn{8}{|c|}{ Glass Alteration at $300{ }^{\circ} \mathrm{C}$ and $\sim 1300 \mathrm{psi}$} \\
\hline 1 & 7.72 & Heulandite & 17.18 & 17.89 & 7.428 & $\mathrm{P}, \mathrm{C}$ & Monoclinic \\
\hline \multirow[t]{2}{*}{2} & 7.75 & Saponite & 5.3 & 9.16 & 12.4 & $\mathrm{P}, \mathrm{C}$ & Monoclinic \\
\hline & & Quartz & 4.9133 & * & 5.4053 & $\mathrm{P}$ & Hexagonal \\
\hline 4 & 7.76 & $*$ & $*$ & $*$ & $*$ & $*$ & $*$ \\
\hline 8 & 7.81 & $*$ & $*$ & $*$ & $*$ & $*$ & $*$ \\
\hline 16 & 7.87 & $*$ & $*$ & $*$ & $*$ & $*$ & $*$ \\
\hline 32 & 7.82 & $*$ & $*$ & $*$ & $*$ & $*$ & $*$ \\
\hline \multirow[t]{4}{*}{64} & 8.03 & Halloysite & 5.14 & 8.9 & 14.9 & $\mathrm{P}, \mathrm{C}$ & Monoclinic \\
\hline & & Sodalite & 8.85 & $*$ & $*$ & $\mathrm{P} / \mathrm{Sc}$ & Cubic \\
\hline & & Wairakite & 13.692 & 13.643 & 13.56 & $\mathrm{P}, \mathrm{C}$ & Monoclinic \\
\hline & & Celadonite & 5.223 & 9.047 & 10.197 & $\mathrm{P}, \mathrm{C}$ & Monoclinic \\
\hline
\end{tabular}

*Represents presence of amorphous phase.

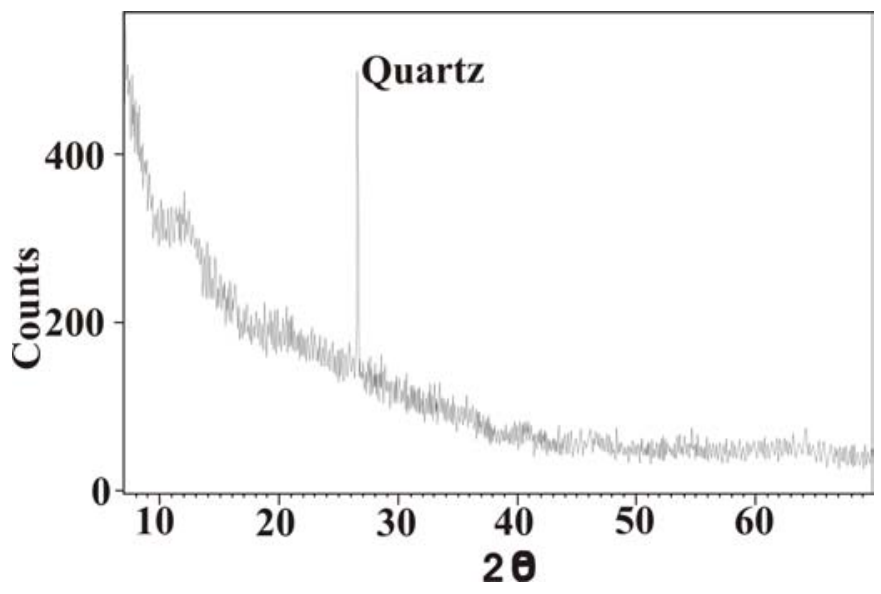

Fig. (6). X-ray diffraction patterns of nuclear waste glass (AVS) showing single anomalous peak of quartz.

kinetic rate laws. The progress is measured in time instead of the non - dimensional variables. A mineral dissolves into fluids under saturated condition and precipitates when it is supersaturated. The pure solid-phase formation is directly related to the speciation in the aqueous phase i.e. the conversion of the solid phase is accountable for the change in the solubility of elements [52]. Most of the current models for predicting borosilicate waste glass dissolution rates assume surface reaction control of dissolution rate and that only the silica concentration of the solution affects the overall rate [30]. The process is therefore modeled using an affinity in terms of $\mathrm{SiO}_{2}$ (aq) only. The models of assume that the glass dissolution rates are exclusively a function of glass composition, temperature, $\mathrm{pH}$, and solution silica concentration. The equilibrium distribution of aqueous species in a fluid, the fluids saturation state with respect to minerals, the sorption of aqueous species onto various types of surfaces has been calculated. Since the chemical composition of the waste glass is similar to that of the aluminosilicate minerals observed in the natural environments, the major alteration-phases are expected to be aluminosilicate phases.

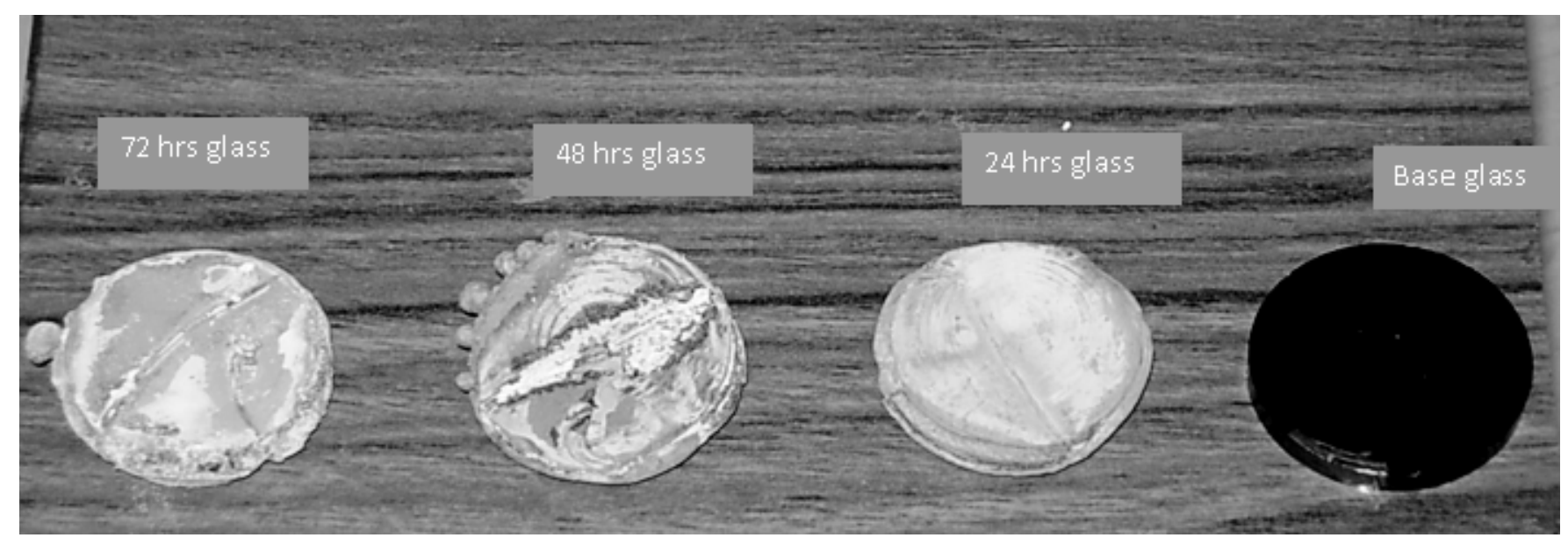

Fig. (7). Cross section of the pellet. 


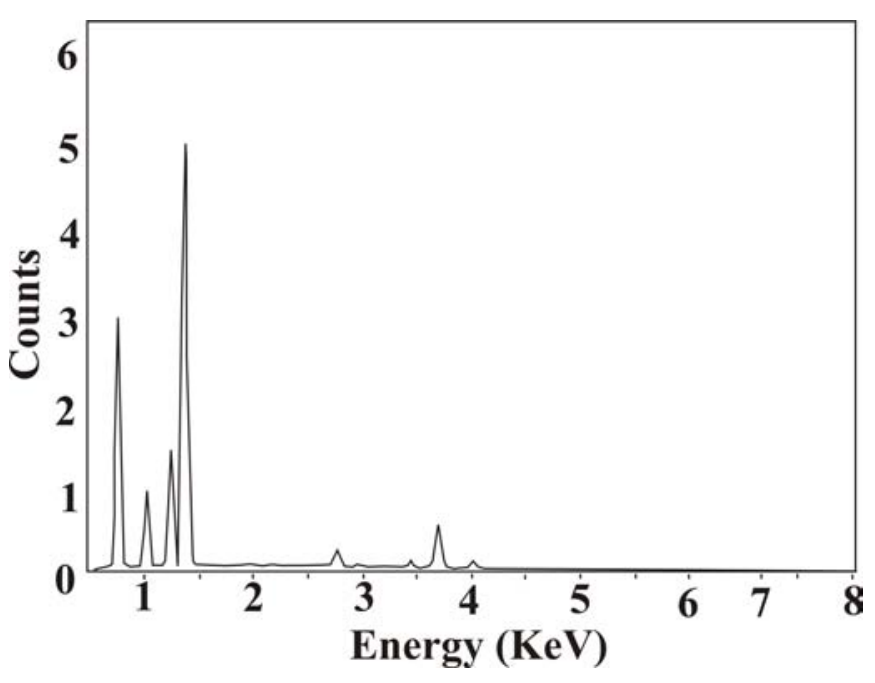

Fig. (8). EDS spectra of nuclear waste glass (AVS).

Thermodynamic calculations have been applied for prediction of the potential alteration-phases formed during the long-term disposal periods. It indicates that amorphous silica, chalcedony, analcime, smectite, kaolinite, gibbsite, or other mineral phases are formed depending upon the glass composition, solution conditions and reaction progress [55]. It has been stated that due little considerate of the formation mechanism, kinetics is also supposed to be one of the important cause for disagreement [56]. These models helped to find out the stability of secondary mineral phases in these experiments if carried out for a longer period. Hence discrepancy between the predicted phases and the actually formed minerals is partly caused by uncertainty in the thermodynamic data, because actually forming phases are non-ideal phases with impurity and crystallographic defects. The initial solution composition including all species involved in further reaction was computed. Understanding of these calculations is required because many factors contribute to the nucleation and growth of a secondary phase includes kinetic constraints on precipitation [57].

Glass composition, temperature, pressure and $\mathrm{pH}$ conditions (such as 8.03 at $300^{\circ} \mathrm{C}$ ) were considered in the assessment of experimental and simulated results. These results were extrapolated for 100 years by plotting (Fig. 11) Mineral saturation $(\log \mathrm{Q} / \mathrm{K})$ data where $\mathrm{Q}$ is the activity constant, product of aqueous species involved in the dissolution reaction for dissolving solid, and $\mathrm{K}$ is the equilibrium constant for the same solid values against time in years [58]. When data extrapolated for 100 years it is observed that quartz is forms up to the period of 5 years whereas, tridymite forms between 15 to 25 years; amorphous silica, chalcedony and cristobalite appear after 40 years (Fig. 11). Reaction progress is plotted against saturation index $(\log \mathrm{Q} / \mathrm{K})$, indicating saturation with respect to a solid phase. It is also assumed that that the glass dissolves congruently, hence saturation indices for each mineral phase is considered.

In the present experimental results for the obsidian glass alteration, $\mathrm{Na}$ was found to be released preferentially therefore; simulation procedure estimates the saturation indices for solid phases that contain $\mathrm{Na}$. It shows that chalcedony and Na-beidellite is formed at a $\mathrm{pH}$ value of 8.03 (sample is treated at $300^{\circ} \mathrm{C}$ and $1300 \mathrm{psi}$ ). The extrapolation of these experimental data nuclear waste glass (AVS) for 100 years revealed that the end members such as iron rich fayalite and greenalite are formed in case of AVS glass (Fig. 12). Presence of quartz is corroborated by XRD data whereas; phyllosilicate grains were identified in the SEM (Fig. 7). At known temperature, the equilibrium system exists as a closed system whereas, pressure affects the equilibrium state but, on a minor scale under near surface conditions $[59,60]$. The temperature -activity and temperature - fugacity relations shows the effects of temperature on the stability of minerals and the predominance of aqueous species in the chemical systems. Thermal stability of glass species versus $\mathrm{pH}$ data plots show presence of iron rich minerals such as greenalite and fayalite. Similar phyllosilicate sequence has been described by in the alteration facies of pillow lavas in the Viviane and Fuchsia drill holes at Mururoa atoll [61]. The formation of secondary phases has significant effect on glass dissolution rates, controlling the concentrations of dissolved elements such as aluminium and silicon [62]. For this reason the abrupt increase in the dissolution rates is observed. The elevated participation of ion exchange process, particularly when high $\mathrm{S} / \mathrm{V}$ ratio of the test sample is available, causes overall release of elements which perhaps is responsible for the increase in the $\mathrm{pH}$ values of the leachates. Hence, release of sodium ions from the glass matrix is primarily responsible for the elevation of alkalinity in the leachates. It has been found that at $300^{\circ} \mathrm{C}$ maximum release of sodium ions takes place (Fig. 13).

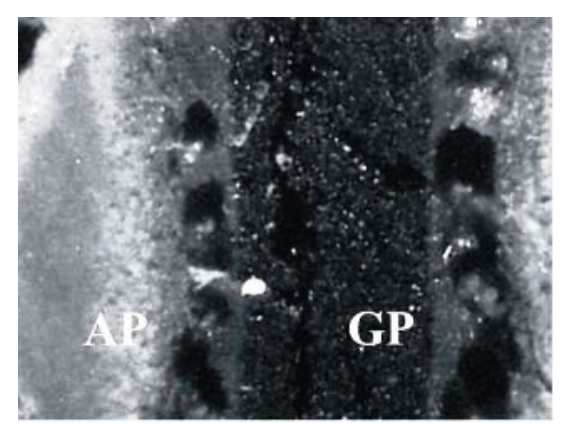

$24 \mathrm{hrs}$

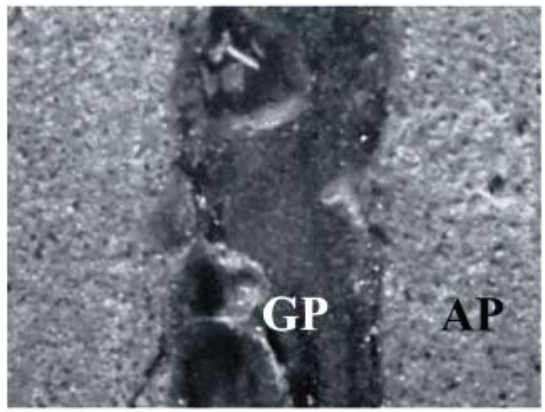

48hrs

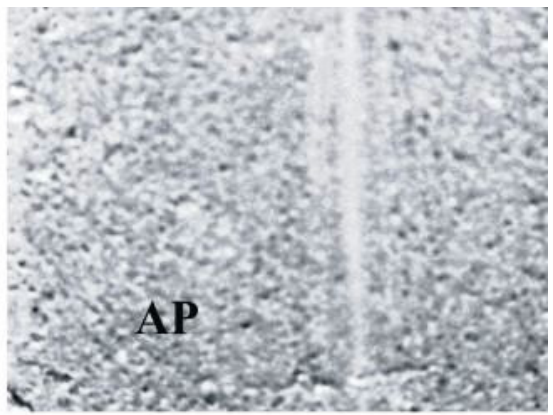

$72 \mathrm{hrs}$

Fig. (9). Photomicrograph $(60 \mathrm{X})$ represents cross-section of an altered pellet under optical microscope showing glassy phase (GP) and altered porous layers (APL). 


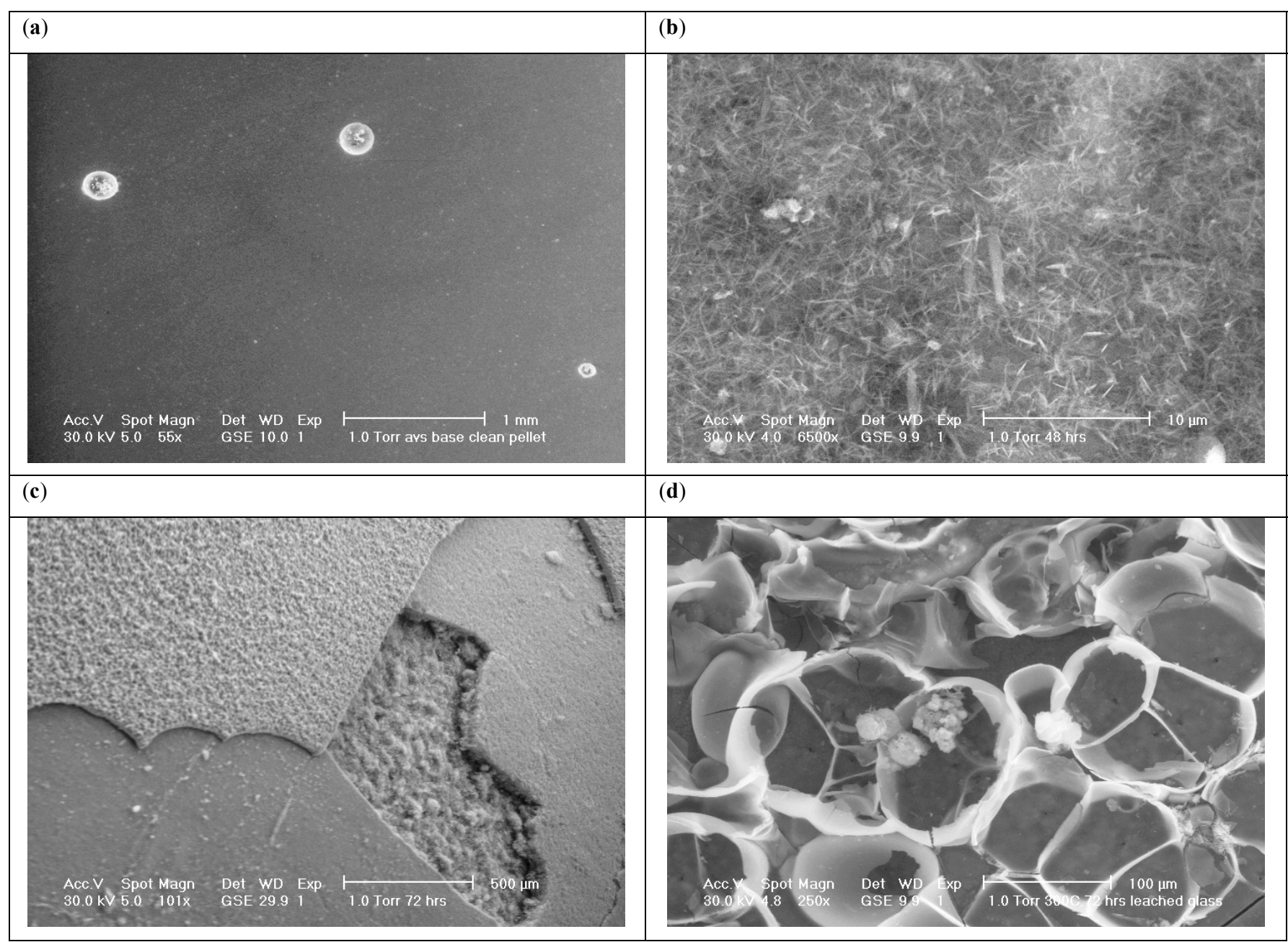

Fig. (10). SEM Micrographs of (a) unleached glass surface, (b) spherules embedded in phyllosilicates, (c) surface with altered layers of glass after 72 hours of treatment with water and (d) phyllosilicates in the glass surface.

\section{CONCLUSION}

The dissolution behaviour of obsidian glass was investigated and compared with AVS glass through conducting various alteration experiments in Parr reactor for 64 hours at 100,200 and $300^{\circ} \mathrm{C}$. In case of nuclear waste glass (AVS) owing to its massive weight loss the experiments were carried out for shorter duration (ranging from 15 mins to 4 hours). It is observed that the temperature and time has immense role in the glass dissolution mechanism. At $300^{\circ} \mathrm{C}$ for 64 hours average dissolution rate is awfully elevated, hence glass alteration increases with rising temperature. It has been concluded that the precipitation of analcime after several weeks of reaction correlates with an abrupt increase in the glass dissolution rate. At low temperature, increase in the glass alteration with time takes place. Release of $\mathrm{Na}, \mathrm{K}$ and $\mathrm{Fe}$ ions indicate that the sodium ion concentration increases commonly in AVS glass, however in case of obsidian, preferential release of potassium ions is observed, indicating large scale break-up of the glass network. Thus, more glass dissolution is taking place.

XRD patterns in case obsidian glass indicate that the new mineral phases were formed when alteration rate is high.
These minerals appear when $\mathrm{pH}$ and conductivity values are 8.03 and $140.9 \mathrm{mhos} / \mathrm{cm}$. Ion-exchange reaction controls the dissolution of obsidian glass at $100^{\circ} \mathrm{C}$ temperature and after that network hydrolysis and ion exchange reactions together control the aqueous alteration behaviour of obsidian glass. At this point the rate of sodium and potassium release is also found high. It has been found that obsidian glass network structure shows high order of durability. Present study revealed an agreement between experimentally observed mineral phases and the mineral phases that obtained through computer simulation of the chemical data (Fig. 11). The appearance of quartz in both the cases is highly likely. Through, extrapolation of experimental constraints, different end members such as amorphous silica (which is least thermodynamically stable), quartz, (the most stable) and chalcedony (having intermediate stability) are formed. Owing to experimental constraints, inconsistency between experimental and simulated results is also noticed to some extent. The elevated participation of ion exchange process at high $\mathrm{S} / \mathrm{V}$ ratio (of the test sample) causes overall release of elements which perhaps is responsible for the increase in the $\mathrm{pH}$ values of the leachates. Through computer simulation of the chemical data quartz is formed in case of AVS glass. Through extrapolation of experimental data for 100 years, it 

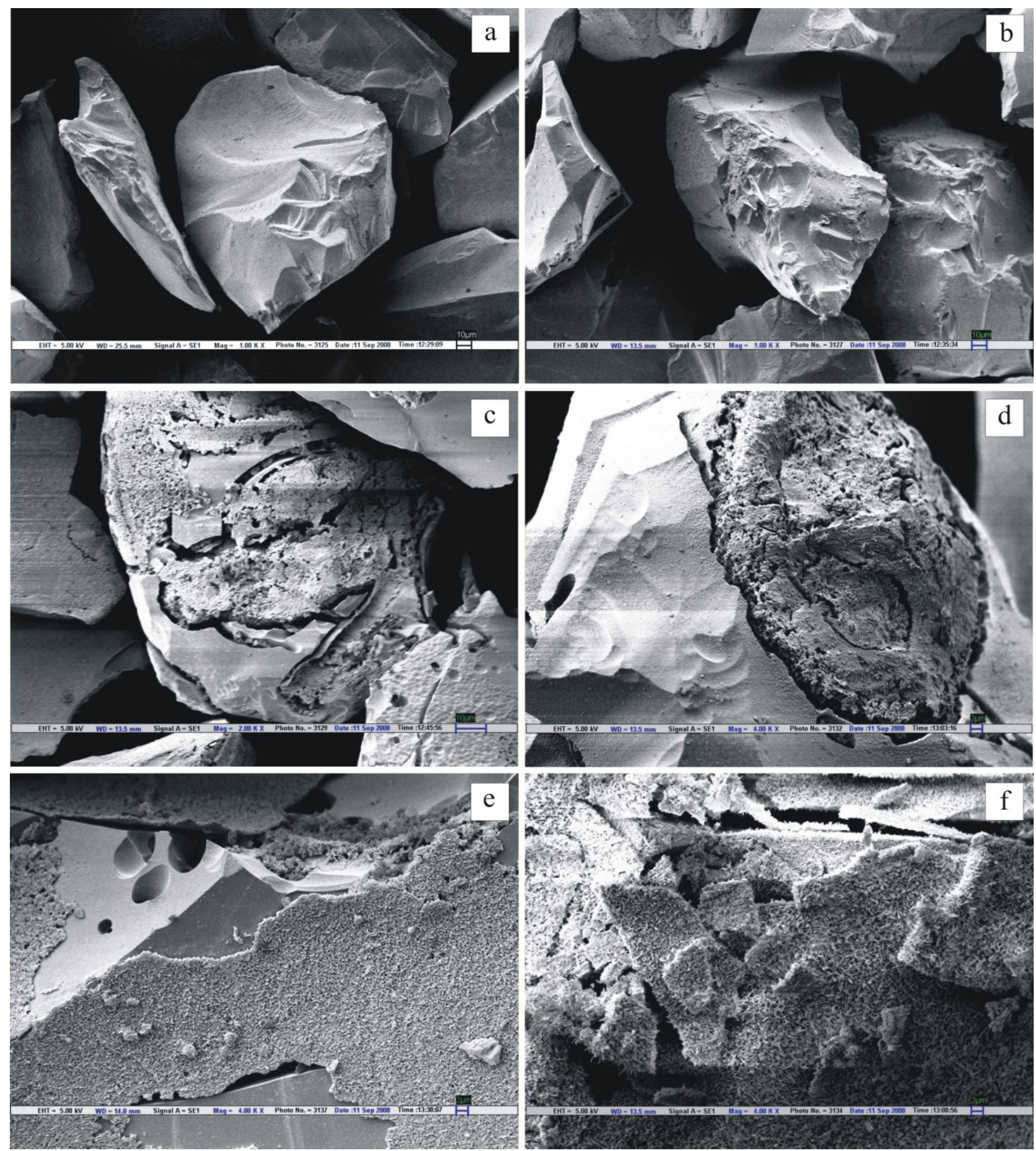

Fig. (11). SEM - Back Scattered electron images of obsidian at different temperature and time. (a) Unaltered, (b) altered at $100^{\circ} \mathrm{C}$ for 1 hour, (c) altered at $100^{\circ} \mathrm{C}$ for 32 hours, (d) altered at $300^{\circ} \mathrm{C}$ for 2 hours, (e) altered at $300^{\circ} \mathrm{C}$ for 64 hours and (f) altered at $300^{\circ} \mathrm{C}$ for 64 hours..

is concluded that the iron rich end members (fayalite and greenalite) are formed (Fig. 12). Appearance of quartz in the residue is corroborated by its XRD patterns. Presence of phyllosilicate is inferred under the SEM. The formation of protective surface layers reduces the rate of corrosion.
Unprotective surface layers have a porous structure which does not significantly influence the reaction rates. The protective surface layer serves as physical mass transport (diffusion) barriers that inhabit further glass reactions by 


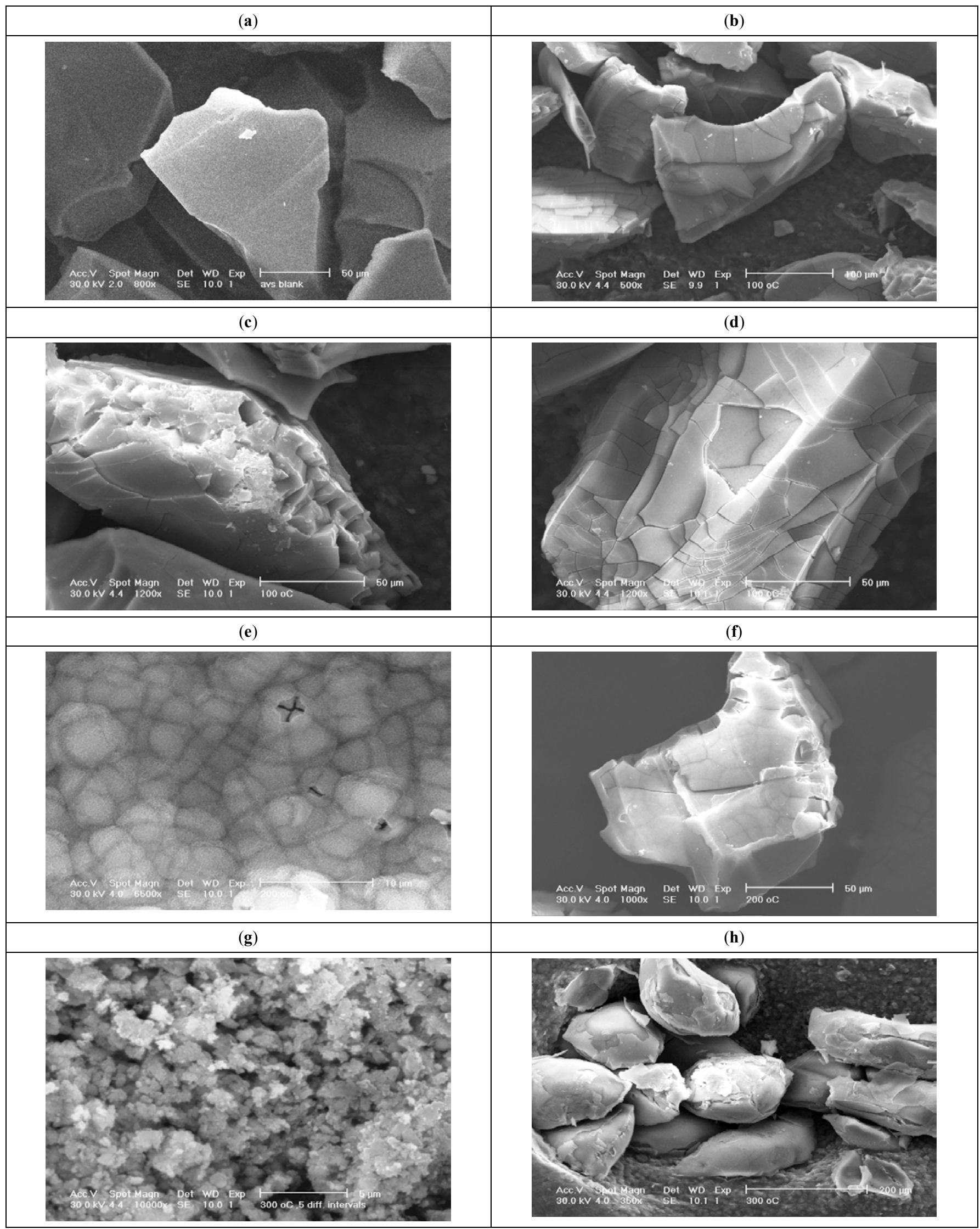

Fig. (12). SEM Micrographs of glass granules showing (a) unleached glass granule. (b) surface of the rim appears foliated like a clay mineral, (c) whole rim is more bulky, (d) consists of equidimensional glass grains with shard morphology, (e) and (f) glass particles with clean surfaces, (g) glass surfaces clustered to form massive aggregates and (h) platy flakes similar to smectite.. 


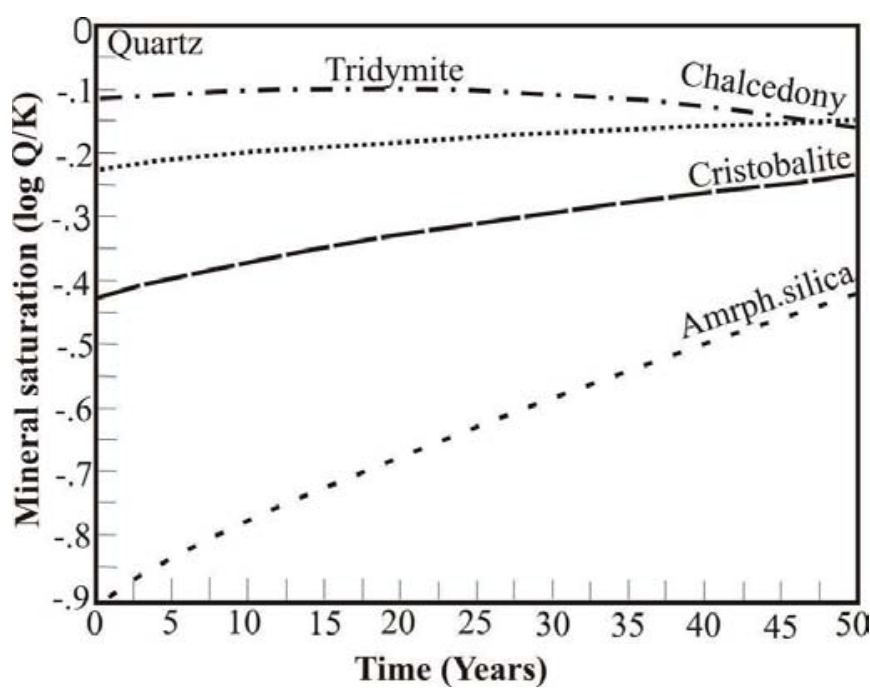

Fig. (13). Extrapolation of experimental data with respect of time.

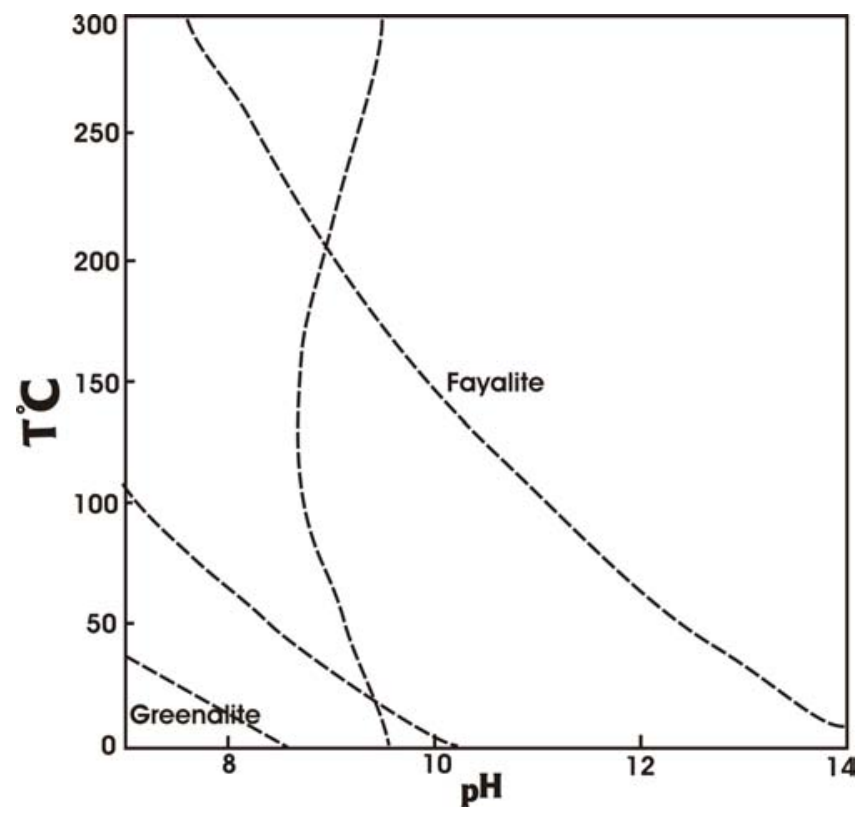

Fig. (14). Extrapolation of thermal stability of glass species vs. $\mathrm{pH}$ showing appearance of greenalite and fayalite along the curve.

impeding the transport of reactants and products [49]. It wasalso found that after the corrosion experiments the surface of the glass became porous. Hence, surface layer formed at $300^{\circ} \mathrm{C}$ was less porous than that formed at $100^{\circ} \mathrm{C}$ and $200^{\circ} \mathrm{C}$. It is concluded that the surface layer formed at $300^{\circ} \mathrm{C}$ is protective, while that formed at lower temperature $\left(100\right.$ and $\left.200^{\circ} \mathrm{C}\right)$ is unprotective. Thus, the effect of glass corrosion and elemental release is reduced due to the formation of protective surface layer. Sequence of mineral precipitation in obsidian and nuclear waste glass (AVS) indicates that an end member of the obsidian glass is more stable than the end members of nuclear waste glass (AVS).

\section{ACKNOWLEDGEMENTS}

Authors acknowledge Board of Research in Nuclear Sciences and Bhabha Atomic Research Centre, Department of Atomic Energy for providing financial assistance towards this work in the form of a Project Grant (No. 2005/36/48/BRNS). We acknowledge Mr. S. D. Mishra,
Director, Nuclear Recycle Group, BARC, Mumbai and Mr. P. K. Narayan Head, Repository Programme Section, BARC, Mumbai for valuable guidance towards this work.

\section{REFERENCES}

[1] Culler F Jr, Ed. Management of Waste from the LWR Fuel Cycle. International Symposium Proceedings (U.S. Energy Research and Development Administration CONF-76-0701. 1976.

[2] Dickin AP. Hydrothermal leaching of rhyolite glass in the environment has implications for nuclear waste disposal. Nature 1981; 294: 342 .

[3] Johnson KDB, Marples JAC. Ukaea 1979 Harwell, AERE-R-9417 HMSO, London 1979.

[4] Roberts L. Radioactive waste policy and perspective. Atom 1979; 267: 8. Retraction of: Dickin AP. Hydrothermal leaching of rhyolite glass in the environment has implications for nuclear waste disposal. Nature 1981; 294: 342 .

[5] Shrivastava JP, Bajpai RK, Rani N. A Review on corrosion mechanism in borosilicate nuclear waste glass for long-term performances assessments in geological repository. J Geol Soc India 2008; 72: 238.

[6] Vaswani GA, Jahgirdar PB, Rastogi RC, et al. Report BARC 1979; p. 1028.

[7] Ebert WL, Mazer JJ. Laboratory testing of waste glass aqueous corrosion; effects of experimental parameters. Mater Res Soc Symp Proc 1994; 333; 27.

[8] Small JS, Trivedi DP, Abraitis PK. Modeling of glass dissolution and transport with the code SUGAR. Mater Res Soc Symp Proc 1998; 506: 253.

[9] Shelby JE. Structure of glasses. Retraction of: introduction to glass science and technology. J R Inst Chem Cambridge 1997; 5: 69.

[10] Gislason SR, Arnorsson S. Dissolution of primary basaltic minerals in natural waters: saturation state and kinetics. Chem Geol 1993; 105: 117 .

[11] Bales RC, Morgan JJ. Dissolution kinetics of chrsotile at $\mathrm{pH} 7$ to 10. Geochim Cosmochim Acta 1985; 49: 2281.

[12] Furrer G, Stumm W. The coordination chemistry of weathering I. Dissolution kinetics of $\sigma-\mathrm{Al}_{2} \mathrm{O}_{3}$ and $\mathrm{BeO}$. Geochim Cosmochim Acta 1986; 50: 1847 .

[13] Blum A, Lasaga A. Role of surface speciation in the low temperature dissolution of minerals. Nature 1988; 331: 431.

[14] Guy C, Schott J. Multisite surface reaction versus transport control during the hydrolysis of a complex oxide. Chem Geol 1989; 78: 181 .

[15] Stumm W, Wollast R. Coordination chemistry of weathering kinetics of the surface-controlled dissolution of oxide minerals Rev Geophys 1990; 28: 53.

[16] Berger G, Claparols C, Guy C, et al. Dissolution rate of a basalt glass in silica-rich solutions: implications for long-term alteration. Geochim Cosmochim Acta 1994; 58: 4875.

[17] Ewing RC, Jercinovic MJ. Alteration of basalt glasses: implications for modelling the long-term stability of nuclear waste glasses. Mater Res Soc Symp Proc 1985; 84: 67.

[18] Crovisier JL, Thomassin JH, Juteau T, et al. Experimental seawater basaltic glass interaction at $50^{\circ} \mathrm{C}$ : Study of early developed phases by electron microscopy and X-ray photoelectron spectrometry. Geochim Cosmochim Acta 1983; 47: 377.

[19] Malow G, Lutze W, Ewing RC. Alteration effects and leach rates of basaltic glasses: implications for the long-term stability of nuclear waste form borosilicate glasses. J Non-Cryst Sol 1984; 67: 305.

[20] Crovisier JL, Vernaz E, Dussossoy JL, et al. Early phyllosilicates formed by alteration of R7T7 glass in water at $250^{\circ} \mathrm{C}$. Appl Clay Sci 1992; 7: 45.

[21] Morganstein ME, Wicket CL, Barkatt A. Considerations of hydration-rind dating of glass artifacts: alteration morphologies and experimental evidence of hydro geochemical soil-zone pore water control. J Archaeol Sci 1999; 26:1193.

[22] Merritt WF. Proceeding Symposium Management of radioactive wastes from nuclear fuel cycle 2, IAEA Vienna 1976; 27. Retraction of: Karkhanis SN, Bancroft GM, Fyfe WS, Brown JD. Leaching behaviour of rhyolite glass. Nature 1980; 284: 435.

[23] Strathdee GG, Mclntyre NS, Taylor P. Development of aluminosilicate and borosilicate glasses as matrixes for CANDU 
high-level waste. International Symposium Proceedings Cincinnati CONF-790420 US DOE 1979; p. 243.

[24] Lipman PW, Christiansen RL, Van Alstine RE. Retention of alkalis by calc-alkalic rhyolites during crystallization and hydration. J Am Miner 1969; 54: 286.

[25] Zielinski RA, Lipman PW, Millard HT. Minor-element abundances in obsidian, perlite, and felsite of calc-alkalic rhyolites. J Am Miner 1977; 62: 426.

[26] Karkhanis SN, Bancroft GM, Fyfe WS, et al. Leaching behaviour of rhyolite glass. Nature 1980; 284: 435 .

[27] Dickin AP. Hydrothermal leaching of rhyolite glass in the environment has implications for nuclear waste disposal. Nature 1981; 294: 342 .

[28] Malow G, Ewing RC. Nuclear waste glasses and volcanic glasses: a comparison of their stabilities. Material Research Society Symposium Proceedings, Scientific Basis for Nuclear Waste Management III 1981; p. 315.

[29] Byers CD, Jercinovic MJ, Ewing RC, et al. Basalt glass: an analogue for the evaluation of the long term stability of the nuclear waste form borosilicate glasses. Mater Res Soc Symp Proc 1985; 44: 583 .

[30] Grambow B. A general rate equation for nuclear waste glass corrosion. Mater Res Soc Symp Proc 1985; 44: 16.

[31] Lutze W, Malow G, Ewing RC, et al. Alteration of basalt glasses: implications for modelling the long-term stability of nuclear waste glasses. Nature 1985; 314: 252.

[32] Ewing RC, Jercinovic MJ. Natural Analouges: Their application to the prediction of long-term behaviour of nuclear waste glasses. Mater Res Soc Symp Proc 1987; 84: 67.

[33] Murakami T, Banba T, Jercinovic MJ, et al. Formation and evolution of alteration layers on borosilicate and basalt glasses. Initial stage, in Scientific Basis for Nuclear Waste Management. Mater Res Soc Symp Proc 1989; 127: 65.

[34] Abdelouas A, Crovisier JL, Lutze W, et al. Formation of hydrotalcite-like compounds during R7T7 nuclear waste glass and basaltic glass alteration. Clays Clay Miner 1994; 42: 526.

[35] Wolery TJ. EQ3/6 a [Software Package] or geochemical modelling of aqueous systems, package overview and installation guide Version 7.0 Lawrence Livermore National Laboratory 1992.

[36] Bethke CM. The Geochemist's Workbench [Software Package] Version 6.0. University of Illinois at Urbana-Champaign 1998.

[37] Le Maitre RW. A proposal by the IUGS Sub commission on the Systematic of Igneous Rocks for a chemical classification of volcanic rocks based on the total alkali silica (TAS) diagram. J Petrol 1976; 17: 589.

[38] Le Maitre RW. Numerical petrology. New York: Elsevier 1982.

[39] Munier I, Crovisier JL, Grambow B, et al. Modelling the alteration gel composition of simplified borosilicate glasses by precipitation of an ideal solid solution in equilibrium with the leachant. J Nucl Mater 2004; 324: 97-115.

[40] Hamilton EH, Cleek GW, Grauer OH. Some properties of glasses in the system Barium oxide - Boric oxide- Silica. J Am Ceram Soc 1958; 41: 209 .

[41] Burnett DG, Douglas RW. Nucleation and crytallization in the soda-baria- silica system. Phys Chem Glasses 1971; 12: 117.

[42] Alekseeva ZD, Mazurin OV, Averjanov V, et al. Sodium borosilicate and porous glasses. Stekla 1977; 3: 114 .

[43] Sheng J, Shanggeng L, Tang B. The leaching behaviour of borate waste glass SL-1. Waste Manage 1999; 19: 401-407.
[44] Kaushik CP, Mishra RK, Sengupta P, et al. Barium borosilicate glass - a potential matrix for immobilization of sulphate bearing high-level radioactive liquid waste. J Nucl Mater 2006; 358: 129138.

[45] Hench LL, Clark DE, Harker AB. Review Nuclear waste solids. J Mater Sci 1986; 21: 1457-78.

[46] Feng X, Cunnane JC, Bates JK. A literature review of surface alteration layer effects on waste glass behaviour. American Ceramic Society Annual Meeting, Cincinnati, Ohio: USA 1993.

[47] Schott J, Berner RA. Dissolution mechanisms of pyroxenes and olivines during weathering. Retraction of: Drever JI, Ed. The Chemistry of Weathering Reidel, Boston, MA 1984; pp. 35-54.

[48] Deer WA, Howie RA, Zussman J. An introduction to the forming rock forming minerals. $2^{\text {nd }}$ ed. London: Longman 1966; pp. 255 391.

[49] Brady PV, Walther JV. Controls on silicate dissolution rates in neutral and basic $\mathrm{pH}$ solutions at $25^{\circ} \mathrm{C}$. Geochim Cosmochim Acta 1989; 53: 2823-2830.

[50] Strachan DM, Croak TL. Compositional effects on long-term dissolution of borosilicate glass. J Non Cryst Sol 2000; 272: 22-33.

[51] Ebert WL. The effects of leachate $\mathrm{pH}$ and the ratio of glass surface area to leachant volume on glass reaction. Phys Chem Glasses 1993; 34(2): 58

[52] Neck V, Fanghanel Th, Kim JI. Aquatische Chemieund Thermodynamische ModellierungvontrivalentenAktiniden Report FZKA 6110Forschungszentrum Karlsruhe 1998.

[53] Dana JD. The Manual of Mineral Science $22^{\text {nd }}$ ed. New York: John Wiley and Sons 2002; pp. 556-561.

[54] Bourcier WL. Affinity Functions for Modeling Glass Dissolution Rates Atomic Energy Commission-Vallee due Rhone Summer. Workshop: Glass: Scientific Research for High Performance Containment Mejannes-le-Clap, France 1997.

[55] Inagaki Y. Geochemical aspects of long-term behaviour of glass waste form Retraction of: Inagaki Y, Shinkai A, Idemistu K, et al. 2005. Aqueous alteration of Japanese simulated waste glass P0798: Effects of alteration-phase formation on alteration rate and cesium retention. J Nucl Mat 2006; 354: 171.

[56] McGrail BP, Ebert WL, Bakel AJ, et al. Measurement of kinetic rate law parameters on a NA-Ca-Al borosilicate glass for lowactivity waste. J Nucl Mater 1997; 249: 175-189.

[57] Cunnane JC, Bates JK, Ebert WL, et al. High level nuclear waste borosilicate glass: a compendium of characteristics. Scientific Basis for Nuclear Waste Management Symposium Boston, MA 1992.

[58] Helgeson HC. Thermodynamics of hydrothermal systems at elevated temperatures and pressures. Am J Sci 1969; 267: 729-804. Hemley RJ, Mao HK, Bell PM, et al. Raman spectroscopy of silica glass at $\mathrm{SiO}_{2}$. Phys Rev Lett 1986; $57: 747-750$

[60] Dudoignon P, Meunier A, Beaufort D, et al. Hydrothermal alteration at Mururoa atoll (French Polynesia), Proc. 5th Int. Syrup on Water-Rock Interaction. Int Assoc Geochem Cosmochem 1986: pp. 175-7.

[61] Van IP, Grambow B. The long-term corrosion and modeling of two simulated Belgian high-level reference waste glasses. Mater Res Soc Symp Proc 1988; 112: 631-639.

[62] Cunnane JC, Bates JK, Ebert WL, et al. High-level nuclear waste borosilicate glass: a compendium of characteristics Scientific Basis for Nuclear Waste Management Symposium Boston, MA 1992. 